\title{
Antibody-independent Classical Pathway-mediated \\ Opsonophagocytosis of Type Ia, Group B Streptococcus
}

\author{
Carol J. Baker, Morven S. Edwards, Bette J. Webb, and Dennis L. Kasper, \\ Department of Pediatrics, Microbiology and Immunology, Baylor College of \\ Medicine, Houston, Texas 77030; Channing Laboratory and Departments of \\ Medicine, Peter Bent Brigham, Division of Affiliated Hospital Center Inc., \\ Beth Israel Hospital and Harvard Medical School, Boston, Massachusetts \\ 02115
}

AB S T R A C T The opsonophagocytic requirements of human sera containing endogenous complement for a variety of type Ia, and group B streptococcal strains were defined. Significant reduction $(\geqq 90 \%)$ in colonyforming units was noted after a 40-min incubation for the highly encapsulated, mouse-passed prototype strain 090 by sera containing moderate to high concentrations of antibody to type Ia polysaccharide (mean, 16.5 $\mu \mathrm{g} / \mathrm{ml}$ ), whereas bacterial growth occurred in 25 sera with low levels of specific antibody (mean, $2.1 \mu \mathrm{g} / \mathrm{ml}$ ). This absolute requirement for a critical amount of specific antibody in promoting opsonophagocytic killing of strain 090 was not found when 18 fresh clinical type Ia isolates were tested. In antibody-deficient and agammaglobulinemic sera, respectively, mean reductions in colony-forming units of 94 and $95 \%$ were seen for fresh clinical isolates, whereas strain 090 was not killed by polymorphonuclear leukocytes in the presence of these sera. All strains required a considerable amount of specific antibody for alternative pathwaymediated opsonophagocytosis. That opsonophagocytic killing of clinical type Ia isolates was mediated by the classical pathway in a nonantibody-dependent fashion was shown when MgEGTA chelation of agammaglobulinemic serum or use of serum deficient in $\mathrm{C} 2$ resulted in bacterial growth. The addition of $\mathrm{C} 2$ to $\mathrm{C} 2$-deficient serum restored bactericidal activity of this serum. These experiments indicate that substances other than the exposed surface of the type Ia capsular polysac-

This work was presented in part to the Society for Pediatric Research, San Francisco, Calif., 28 April 1981.

Dr. Baker is the recipient of National Institute of Allergy and Infectious Diseases Research Career Development Award $1 \mathrm{~K} 04 \mathrm{AI}$ 00323. Dr. Kasper is the recipient of National Institute of Allergy and Infectious Diseases Research Career Development Award 1 K04 AI 00126.

Received for publication 7 July 1981 and in revised form 22 September 1981. charide initiate classical pathway-mediated opsonophagocytosis of clinical isolates of type Ia, group B streptococci by human sera in the absence of immunoglobulin. Perhaps, a deficiency in classical complement pathway function is critical to the susceptibility of neonates to type Ia, group B streptococcal disease.

\section{INTRODUCTION}

Our previous studies (1-3) have indicated that neonates at significant risk for the development of invasive type III, group B streptococcal infection are those with a deficiency of maternally acquired antibody with specificity for the native type III capsular polysaccharide, although other host defense mechanisms may assist in limiting infection to mucous membranes. The mechanism by which this transplacentally acquired anticapsular antibody mediates protective immunity is incompletely understood. However, recently it has been demonstrated that human sera containing a critical amount of this antibody will initiate complementmediated opsonophagocytosis of type III organisms via both the classical and the alternative pathway. In the absence of antibody, no opsonophagocytic killing occurs. Of interest, if the terminal sialic acid residue of the type III capsule is removed by neuraminidase treatment, nonantibody-dependent activation of the alternative pathway results, and type III organisms are ingested by polymorphonuclear leukocytes and killed (4). How this antibody with specificity for the terminal sialic acid residues on the repeating unit of the type III capsular polysaccharide (5) permits activation of the alternative pathway is unknown. Utilization of this important mechanism of natural immunity by the host, however, is dependent upon the presence of sufficient concentrations of specific antibody.

Another serotype of group B Streptococcus respon- 
siblo for invasive infection in neonates is type Ia. In contrast to type III strains, however, almost all of these infections have their onset in the first few days of life. The structures of the capsular polysaccharides of these two serotypes are similar in that terminal sialic acid residues completely mask underlying galactopyranose groups, although the specific linkages and locations of these two monosaccharides and other monosaccharide constituents are different $(5,6)$. Some studies have suggested that a low level of antibody to type Ia polysaccharides in maternal serum, in a manner analogous to serotype III, is a risk factor for neonatal type Ia septicemia $(7,8)$. However, very few sera from these infants or their mothers have been evaluated, and investigations regarding the functional capacity of type Ia-specific antibody have employed the mouse-passed, highly encapsulated type Ia strain Lancefield 090 (also designated Center for Disease Control strain SS615) exclusively (7-9). The present investigation was designed to define the relative role of human antibody to the native type Ia polysaccharide and complement in opsonophagocytosis of both the Lancefield prototype strain 090 and a variety of fresh type Ia, group B streptococcal clinical isolates.

\section{METHODS}

Bacterial strains. 18 clinical isolates of type Ia, group B Streptococcus and the prototype strain 090 (kindly supplied by Dr. Rebecca Lancefield, The Rockefeller University, New York) were evaluated. 12 strains were isolated from neonates with invasive type Ia, group B streptococcal infections (septicemia or meningitis) of varying clinical severity; two strains were isolated from adults with bacteremia. The remaining four strains were vaginal, rectal, or pharyngeal isolates from asymptomatically colonized adults. After primary isolation by the hospital laboratory, the clinical isolates were inoculated into Todd-Hewitt broth (THB) ${ }^{1}$ (Difco Laboratories, Detroit, Mich.), incubated at $37^{\circ} \mathrm{C}$ overnight, and stored at $-70^{\circ} \mathrm{C}$ in 0.5 -ml aliquots. Prototype strain 090 , originally isolated from the blood of an infant, was received in the lyophilized state after 14 passages through mice by $\mathrm{Dr}$. Lancefield.

For the opsonophagocytic assays, a frozen aliquot was streaked onto a blood-agar plate and incubated overnight at $37^{\circ} \mathrm{C}$. Plate-grown organisms were then inoculated into THB and grown for $\sim 2 \mathrm{~h}$ to an OD of 0.3 at $540 \mathrm{~nm}$ (Spectronic 20, Bausch \& Lomb, Inc., Rochester, N. Y.). Cultures grown in this manner were in early log-phase growth $(\sim 3$ $\times 10^{8}$ colony forming units [CFU] $\left./ \mathrm{ml}\right) .30 \mathrm{ml}$ of broth culture was centrifuged at $750 \mathrm{~g}$ for $15 \mathrm{~min}$ at $4^{\circ} \mathrm{C}$, the pellet was resuspended in $16 \mathrm{ml}$ of minimal essential medium (MEM) with Earle's balanced salt solution (Microbiological Associates, Walkersville, Md.), and a 1:10 dilution of this bacterial

${ }^{1}$ Abbreviations used in this paper: CFU, colony-forming units; GVB++, isotonic, pH 7.5, veronal-NaCl buffer containing 0.1 gelatin made to $0.15 \mathrm{mM} \mathrm{Ca}^{++}$and $\mathrm{Mg}^{++}$; $\mathrm{MEM}$, minimal essential medium; THB, Todd-Hewitt broth; WBC, leukocytes. suspension in MEM achieved a bacteria/leukocytes (WBC) ratio of $\sim 3: 1$ in the opsonic reaction mixture.

Laboratory passage of strains. To examine the potential effect of laboratory passage on opsonophagocytic requirements of human sera for prototype strain 090 and two representative clinical isolates, 508 and 515 , several maneuvers were performed. Stock strains were inoculated onto bloodagar plates and incubated overnight at $37^{\circ} \mathrm{C}$. A single colony was selected and streaked for isolation onto another plate. Consecutive passage was continued daily for 3-4 wk. In an attempt to enhance their virulence for mice, strains were inoculated intraperitoneally into 20 - to $25-\mathrm{g}$ female Swiss outbred ICR mice (Timco Breeding Laboratories, Houston, Tex.) and passed serially from spleen homogenates for up to 75 passages according to the method of Lancefield et al. (10). In addition, strains were passed 25 times daily into THB containing a $10 \%$ concentration of a single human serum that contained low levels of antibody to the type Ia polysaccharide $(1.0 \mu \mathrm{g} / \mathrm{ml})$. Aliquots of these laboratory-adapted strains were frozen at $-70^{\circ} \mathrm{C}$ in THB until tested.

Mouse lethality tests. Select type Ia strains of group B Streptococcus were tested for virulence in mice in a way similar to previously described methods (10). Strains were grown overnight in THB to a concentration of $\sim 5.0 \times 10^{8}$ $\mathrm{CFU} / \mathrm{ml}$. For calculation of $\mathrm{LD}_{50}$, all dilutions of broth cultures were made in saline and injected intraperitoneally in l-ml volumes. Dead mice were counted and removed from their cages at $24-h$ intervals. The $L D_{50}$ for a given strain was estimated by the method of Reed and Muench (11).

Electron microscopy. The prototype strain 090 and representative clinical isolate 508 were prepared for electron microscopy after overnight growth in THB to evaluate their degree of encapsulation by ferritin-conjugated type Ia-specific antibody. The details of these methods are described elsewhere (12).

Quantitation of type Ia capsular polysaccharide. To determine whether a difference in amount of type-specific capsular polysaccharide might relate to the difference in opsonophagocytic requirements for the prototype strain 090 , laboratory-adapted strain, and two clinical isolates, the quantity of capsular Ia antigen released into THB was assessed by capillary precipitin reactions of concentrated broth filtrates with hyperimmune rabbit antiserum prepared to type Ia organisms grown at $\mathrm{pH}$ 7.2. Plate-grown strains were inoculated into $200 \mathrm{ml}$ of THB supplemented with glucose (13), incubated in a shaking water bath at $37^{\circ} \mathrm{C}$ while the pH was maintained at 7.0-7.5, and grown to an OD of 0.60 at $650 \mathrm{~nm}$ as determined by a Coleman Junior Spectrophotometer (model 6C, Coleman Systems, Irvine, Calif.). Aliquots were removed six times hourly to determine the viable CFU per milliliter; all strains had $\sim 5 \times 10^{9} \mathrm{CFU} / \mathrm{ml}$ at an OD of 0.6. When the desired OD was achieved, aliquots of broth from each flask were filtered, concentrated in an ultrafiltration apparatus with a PM-10 membrane (Amicon Corp., Lexington, Mass.) to one-fourth the original volume, and tested for precipitin reaction in capillary tubes with hyperimmune type Ia rabbit antiserum. Known concentrations of purified type Ia native polysaccharide were tested simultaneously for a semiquantitative comparison.

Isolation and characterization of the type Ia antigen. The type Ia capsule from group B streptococcal strains 090, 501, and 508 was purified and chemically characterized by methods previously described (6).

Preparation of rabbit antisera. Adult New Zealand White rabbits were immunized with formalin-killed type Ia, group B Streptococcus (strain 090) grown either in non-pHtitrated or pH-titrated THB $(6,13)$ according to the im- 
munization schedule of McCarty and Lancefield (14). Antisera prepared to non-pH-titrated organisms have been shown to have specificity for both core and native Ia antigens, whereas antisera prepared to organisms grown with pH control have antibody primarily directed against the native determinant (6).

Human sera. Aliquots of adult human sera containing a range of concentrations of antibody to the native type Ia polysaccharide and of sera from three healthy neonates obtained within $36 \mathrm{~h}$ of birth were frozen at $-70^{\circ} \mathrm{C}$ within 1 $\mathrm{h}$ of collection. Genetically C2-deficient human serum was obtained from a woman with inactive systemic lupus erythematosis who had normal levels of C3, B, C3 inactivator, and $\beta 1 \mathrm{H}(15)$. This serum was provided through the courtesy of Dr. Anne Nicholson-Weller (Beth Israel Hospital, Harvard Medical School, Boston, Mass.). Agammaglobulinemic serum was obtained from a child with severe combined immunodeficiency (IgG: $10 \mathrm{mg} / 100 \mathrm{ml}$; IgM and IgA: undetectable) and normal complement levels except for $\mathrm{Clq}$, which was 30-40\% of normal levels (4). Complement in selected sera was inactivated by heating to $56^{\circ} \mathrm{C}$ for $30 \mathrm{~min}$.

Specific antibody concentrations. The method employed was identical to that described previously for type III, group B streptococcal antibody $(1,16)$, except that purified native type Ia polysaccharide (extracted from strain 515 ) intrinsically labeled with ${ }^{3} \mathrm{H}$-labeled sodium acetate was employed as the antigen in the radioactive antigen-binding assay. This antigen is a repeating unit of galactose, glucose, glucosamine, and $\alpha$-D- $N$-acetylneuraminic acid (sialic acid) in a molar ratio of 2:1:1:1 (6) and has a specific activity of 5,000 cpm/ $\mu \mathrm{g}$. It has immunologic specificity for type Ia antibody and does not react with group B-specific antibody from hyperimmune rabbit antisera. The methods for the antigen isolation and purification as well as for its immunochemical characterization are detailed elsewhere (6). To relate antigen-binding capacity to antibody concentration, the radioactive antigen-binding capacity of four human sera with known content of precipitating antibody was determined (17). A linear relationship between percentage of antigen bound and $\log$ of antibody concentration was observed.

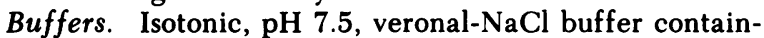
ing 0.1 gelatin made to $0.15 \mathrm{mM} \mathrm{Ca}^{++}$and $0.5 \mathrm{mM} \mathrm{Mg}^{++}$ $(\mathrm{GVB}++)$ was prepared as described previously (4). MgEGTA buffer was made by supplementing GVB to $4 \mathrm{mM}$ $\mathrm{Mg}^{++}$and $16 \mathrm{mM}$ EGTA and adjusting the $\mathrm{pH}$ to 7.5.

Complement components. Purified guinea pig $\mathrm{C} 2$ and human C2 were obtained from Cordis Laboratories Inc., Miami, Fla.

Opsonophagocytic assay. The opsonophagocytic assay of Edwards et al. (18) was employed. The opsonic reaction mixture contained $0.1 \mathrm{ml}$ of $\mathrm{WBC}$ suspension $\left(\cong 1 \times 10^{6}\right.$ WBC), $0.1 \mathrm{ml}$ of bacterial suspension ( $\cong 5 \times 10^{6} \mathrm{CFU}$ ), and $0.1 \mathrm{ml}$ of human serum that contained endogenous complement. When exogenous complement was employed with heated serum as an antibody source or when human C2 was added to C2-deficient serum, the reaction mixture volume increased to $0.4 \mathrm{ml}$. Control tubes lacking WBC, test serum, or complement were included in each assay. Opsonic mixtures were incubated at $37^{\circ} \mathrm{C}$ during end-over-end rotation in a Roto-Rack apparatus (Fisher Scientific Co., Pittsburgh, $\mathrm{Pa}$.) for $40 \mathrm{~min}$. When the classical pathway was inhibited by MgEGTA, the procedure was modified to include a preopsonization step to avoid toxicity to the WBC. Serum diluted 1:2 in MgEGTA or GVB++ as a control were incubated 5 min at $37^{\circ} \mathrm{C}$ to allow EGTA to chelate the available calcium. The procedure was then completed as described previously (18), and the results were expressed as the bactericidal index:

$$
\text { bactericidal index }(\%)=100-\left[\frac{\mathrm{CFU} \text { at } 40 \mathrm{~min}}{\mathrm{CFU} \text { at } 0 \mathrm{~min}} \times 100\right] \text {. }
$$

The results are given as the mean of a minimum of two determinations, unless otherwise indicated.

Absorption of sera. Purified native type Ia, group B streptococcal and purified type 3 pneumococcal polysaccharides were coupled to sheep erythrocytes by the method of Baker et al. (19). This procedure was the same as detailed for type III, group B streptococcal polysaccharide (18), except that $3.0 \mathrm{mg}$ of native type Ia antigen was added to $0.5 \mathrm{ml}$ of packed, washed sheep erythrocytes. Freshly collected sera were added to each antigen-coated erythrocyte pellet, mixed frequently for $3 \mathrm{~h}$ at $4^{\circ} \mathrm{C}$, centrifuged at $750 \mathrm{~g}$ for $15 \mathrm{~min}$, and filtered. The supernatant fluid was aliquoted for storage at $-70^{\circ} \mathrm{C}$ until tested. In addition, selected sera were absorbed in a similar manner with whole type Ia cells (both strain 090 and strain 515) grown overnight in THB and mixed at a bacteria/serum ratio of $1: 5$ (by volume). Serumcell suspensions were mixed frequently for $3 \mathrm{~h}$ at $4^{\circ} \mathrm{C}$, centrifuged, decanted, filtered, and frozen at $-70^{\circ} \mathrm{C}$. Unabsorbed serum controls treated in an identical manner were prepared for both purified type Ia antigen and whole-cell absorption experiments.

Immunofluorescence procedure. Fluorescein isothiocyanate-conjugated specific antibody to human IgG (Meloy Laboratories, Inc., Springfield, Va.) was added to pelleted opsonized or unopsonized bacteria. A 1:12 dilution of labeled conjugate in $0.15 \mathrm{NaCl}$ in a volume of $0.1 \mathrm{ml}$ was added to the pelleted bacteria. Bacterial cells were resuspended, incubated at $4^{\circ} \mathrm{C}$ for $30 \mathrm{~min}$, washed thoroughly with phosphate-buffered saline, and resuspended in $0.1 \mathrm{ml}$ of a mixture of $0.15 \mathrm{M} \mathrm{NaCl}$ and glycerine. This mixture was examined for fluorescence with an ultraviolet microscope (American Optical Corp., Southbridge, Mass.), fluorescence was blindly graded 0 to $4+$ by three observers, and mean values were calculated. Fluorescein isothiocyanate-conjugated specific antibody to Clq (Atlantic Antibodies, Scarborough, Me.) was reacted at a 1:2 dilution with opsonized and unopsonized bacteria. For these experiments, $0.1 \mathrm{ml}$ of agammaglobulinemic serum or purified human $\mathrm{Cl}$ containing $1,000 \mathrm{U}$ were reacted with strains 090 or 515 under conditions identical to those of the opsonophagocytic assays, except that WBC were replaced with $0.1 \mathrm{ml}$ of MEM. The remainder of the procedure for $\mathrm{Clq}$ indirect immunofluorescence was identical to that described above for IgG except that a 1:3 dilution of conjugate was used.

\section{RESULTS}

Human sera that contained endogenous complement and antibody to native type Ia polysaccharide representing a range in concentration from moderate to high $(7.6-32 \mu \mathrm{g} / \mathrm{ml})$ to very low $(<1.8-3.1 \mu \mathrm{g} / \mathrm{ml})$ were selected for evaluation of their opsonophagocytic activity for a variety of type Ia strains. For the Lancefield prototype strain 090 only sera containing moderate to high levels of specific antibody promoted significant opsonophagocytosis ( $\geqq 90 \%$ reduction of $\mathrm{CFU}$ at $40 \mathrm{~min}$ ) (Table I). In contrast, sera from 25 normal adults with low antibody concentrations uniformly failed to cause bacteriolysis of this strain. Heat-inactivated sera did not promote opsonophagocytosis, des- 
TABLE I

Bactericidal Activity for Prototype Type Ia Strain of Group B Streptococcus (090) of 31 Selected Normal Adult Sera

\begin{tabular}{|c|c|c|c|c|c|}
\hline \multicolumn{2}{|c|}{$\begin{array}{l}\text { Type Ia-specific antibody } \\
\text { concentration }\end{array}$} & \multirow{2}{*}{$\begin{array}{c}\text { No. of } \\
\text { sera tested }\end{array}$} & \multicolumn{3}{|c|}{ Bactericidal index } \\
\hline Mean & Range & & Mean & Range & SD \\
\hline \multicolumn{2}{|c|}{$\mu g / m l$} & & & $\%$ & \\
\hline 2.1 & $1.8-3.1$ & 25 & 0 & - & - \\
\hline 16.5 & $7.6-30.9$ & 6 & 92 & 83-95 & 4.3 \\
\hline
\end{tabular}

pite high levels of specific antibody, and bacterial growth was always observed in the absence of complement or WBC.

That the bactericidal activity of adult sera for prototype Ia strain 090 was related to antibody to the native type Ia capsular antigen was demonstrated by absorption of two select sera with whole type Ia cells and purified native type Ia polysaccharide (Table II). When these two sera that contained moderate $(9.0$ $\mu \mathrm{g} / \mathrm{ml})$ or high $(27.5 \mu \mathrm{g} / \mathrm{ml})$ levels of specific antibody were absorbed with whole type Ia organisms or purified native type Ia antigen, the concentration of antibody was markedly reduced, resulting in ablation of their bactericidal activity. Opsonization was unaffected when these same sera were absorbed with purified type 3 pneumococcal polysaccharide or with whole type III, group B streptococcal cells. These experiments indicate a critical role for type Ia-specific antibody in the opsonophagocytosis of the prototype
Ia strain 090 by human sera in the presence of complement.

To assess possible strain differences in opsonic requirements, we compared Lancefield strain 090 with 18 fresh clinical isolates of type Ia, group B streptococci. The opsonophagocytosis of these strains by serum that contained moderate $(9.0 \mu \mathrm{g} / \mathrm{ml})$ or low $(2.0$ $\mu \mathrm{g} / \mathrm{ml}$ ) levels of antibody to native type Ia polysaccharide and by agammaglobulinemic serum is summarized in Fig. 1. Whereas opsonophagocytosis of strain 090 required specific antibody in a sufficient concentration, both serum deficient in type-specific antibody and agammaglobulinemic serum promoted opsonophagocytosis of all 18 fresh clinical isolates, as evidenced by mean bactericidal indices of 94 (range, 83-98\%) and 95\% (range, 77-99\%), respectively. When the bactericidal activity of these three representative sera for the clinical type Ia strains were compared, no differences in opsonization were noted between iso-

TABLE II

Reduction in Opsonophagocytosis of Type Ia Strain 090 after Absorption with Native Type Ia Polysaccharide or Type Ia Cells

\begin{tabular}{lccr}
\hline Serum & Absorption & $\begin{array}{c}\text { Type la GBS } \\
\text { antibody concentration }\end{array}$ & $\begin{array}{c}\text { Bactericidal } \\
\text { index }\end{array}$ \\
\hline & & $\mu g / m l$ & $\%$ \\
NHS $_{1}$ & None & 9.0 & 93 \\
$\Delta$ NHS $_{1}$ & None & 9.0 & 0 \\
NHS $_{1}$ & Type Ia polysaccharide & 2.2 & 0 \\
NHS $_{1}$ & Type 3 pneumococcal SSS & 8.3 & 91 \\
NHS $_{1}$ & Type Ia cells & 1.8 & 0 \\
NHS $_{1}$ & Type III cells & 8.5 & 91 \\
NHS $_{2}$ & None & 27.5 & 95 \\
$\Delta$ NHS $_{2}$ & None & 27.5 & 0 \\
NHS $_{2}$ & Type Ia polysaccharide & 2.5 & 0 \\
NHS $_{2}$ & Type 3 pneumococcal SSS & 26.0 & 94 \\
NHS $_{2}$ & Type Ia cells & 1.8 & 0 \\
NHS $_{2}$ & Type III cells & 24.5 & 92 \\
\hline
\end{tabular}

NHS, serum from an adult donor containing the antibody concentration specified carried through the absorption procedure at $4^{\circ} \mathrm{C}$.

$\triangle \mathrm{NHS}$, serum that was heat inactivated at $56^{\circ} \mathrm{C}$ for $30 \mathrm{~min}$. 
Strain 090

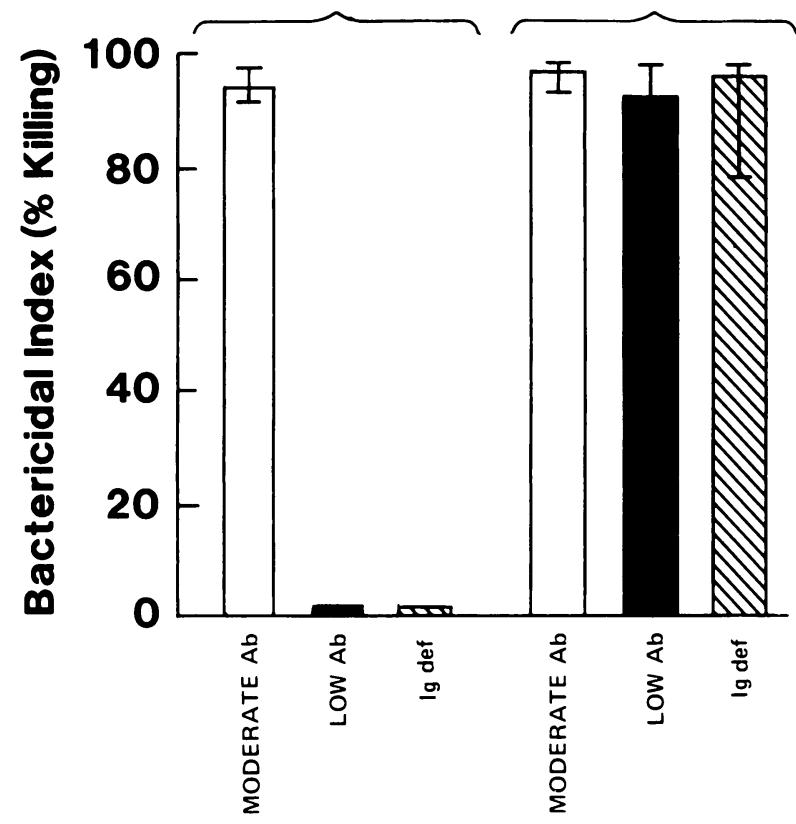

Figure 1 Bactericidal index in opsonophagocytosis of prototype Ia, group B streptococcal strain 090 compared with 18 fresh type Ia clinical isolates by sera containing moderate or low concentrations of type Ia-specific antibody ( $\mathrm{Ab})$, and by agammaglobulinemic serum (Ig def). Mean and range in bactericidal indices of three experiments for each serum are indicated.

lates from infants with bacteremia or meningitis and those from asymptomatic adults (mean bactericidal indices, 92 and $96 \%$, respectively). As noted for prototype strain 090 , bacterial growth of the 18 clinical type Ia isolates always occurred in the absence of complement or WBC.

To determine whether these observed differences in opsonic requirements of adult sera for Lancefield prototype strain 090 (mouse passed 14 times) and representative fresh clinical isolates might be related to relative degree of encapsulation, we performed electron microscopy (Fig. 2) with ferritin-conjugated type Ia-specific antibody. Strain 090 demonstrated a much larger capsule than did strain 508. Similarly, when capsular content of these two strains and one additional fresh isolate, 515, was assessed by semiquantitative determination of extracellular elaboration of capsule into growth medium, strain 090 was found to extrude much more type Ia antigen than clinical isolates (Table III). The yield of isolatable type Ia capsular antigen per liter of broth medium for strain 090 was compared with two clinical isolates, 501 and 508. Strain 090 yielded two times more polysaccharide than did strain 515 and six times more than strain 501. Degree of encapsulation also correlated directly with virulence for mice. However, when prototype strain 090 was repetitively inoculated onto blood-agar medium, this strain became less encapsulated and was quite comparable to clinical isolates with regard to bactericidal index in antibody-deficient serum and virulence for mice. Plate passage of clinical isolates did not alter opsonic requirements or mouse virulence. However, when 090, which had been plate passed 25 times, was consecutively mouse passed for $17 \mathrm{~d}$ or repetitively grown in the presence of THB containing a $10 \%$ concentration of antibody-deficient serum, encapsulation and mouse virulence increased significantly, and serum resistance was restored. In contrast, up to 75 mouse and 25 serum passages failed to influence two fresh clinical isolates with respect to opsonophagocytic requirements and mouse virulence.

Type Ia capsular polysaccharide from strains 090, 501 , and 515 was isolated by methods described elsewhere (6). The capsules from all three strains were identical by chemical and immunologic analyses. Each contained galactose, glucose, glucosamine, and sialic acid in molar ratios of 2:1:1:1. All gave lines of identity by double diffusion in agar gel against type Ia rabbit antisera. Extractions of these three strains with $\mathrm{HCl}$ yielded immunochemically identical type Ia core polysaccharides.

Employing defined sera and experimental conditions that allowed activation of both complement pathways or inhibition of the classical pathway (chelation with MgEGTA), we compared prototype strain 090 with a representative fresh type Ia isolate, 515. Although sufficient concentrations of specific antibody were required for opsonophagocytosis of 090 when both complement pathways were intact, only five of eight sera with moderate to high levels of antibody were able to recruit the alternative pathway to mediate bacterial killing when the classical pathway was blocked. (Table IV). The inability of some chelated sera to promote opsonophagocytosis of strain 090 even in the presence of moderate levels of specific antibody is illustrated by the wide range shown in Fig. 3. Serum deficient in antibody, agammaglobulinemic serum, and C2-deficient serum (also deficient in specific antibody) all failed to promote opsonophagocytosis of strain 090. In contrast, opsonophagocytic killing of strain 515 was mediated by the classical pathway in an antibody-independent fashion (Table V). Serum deficient in specific antibody and agammaglobulinemic serum promoted opsonophagocytosis at means of 97 and $93 \%$ reduction in CFU, respectively, in $\mathrm{GVB}++$ buffer. Inactivation of the classical pathway in agammaglobulinemic serum by chelation of sera with MgEGTA or because of a genetic deficiency in $\mathrm{C} 2$, however, resulted in bacterial growth. Reconstitution of serum deficient in C2 with either human or 

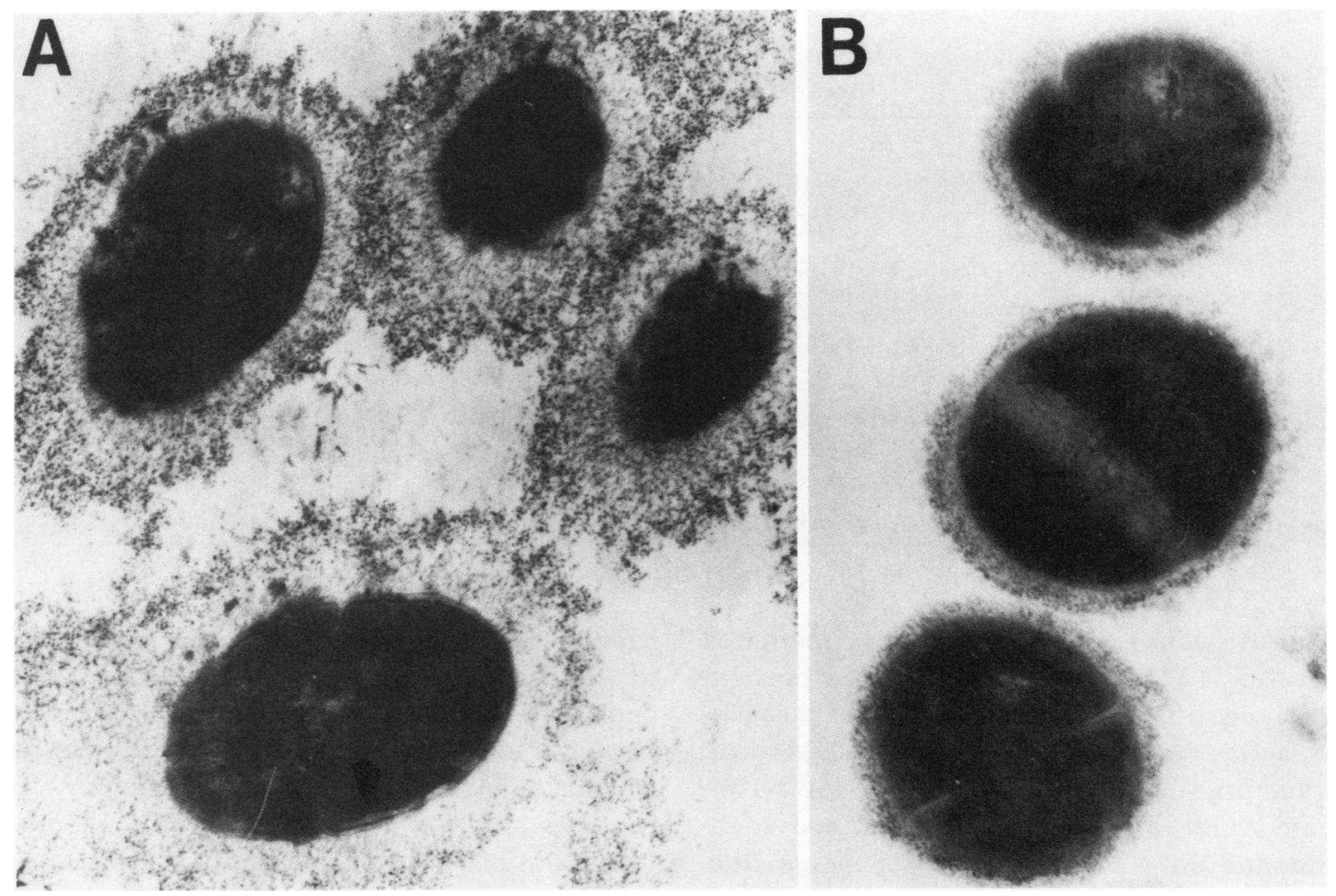

FIGURE 2 Electron micrographs of thin sections of type Ia, group B Streptococcus stained with ferritin-conjugated type Ia antibodies. (A) Lancefield strain 090 demonstrates a large concentration of ferritin particles external to the outer lamina, indicating a large amount of capsular material. (B) Strain 508, a fresh isolate from a neonate with meningitis, demonstrates very little encapsulation for the majority of cells. $\times 15,000$.

guinea pig $\mathrm{C} 2$ restored the bactericidal activity of this serum to 91 and $93 \%$, respectively. Unlike what was observed for strain 090, all sera containing moderate, but not low, levels of specific antibody were able to facilitate opsonophagocytosis of strain 515 via the alternative complement pathway.

TABLE III

Effect of Laboratory Passage on Opsonic Requirements of Human Sera for Representative Type Ia Strains

\begin{tabular}{|c|c|c|c|}
\hline Strain (laboratory passage) & $\begin{array}{l}\text { Quantity of } \\
\text { extracellular } \\
\text { Ia antigen }\end{array}$ & $\begin{array}{l}\text { Bactericidal index } \\
\text { in antibody- } \\
\text { deficient serum } \\
(2.0 \mu \mathrm{g} / \mathrm{ml})\end{array}$ & $\mathrm{LD}_{\mathrm{s0}}$ for mice \\
\hline & \multicolumn{3}{|c|}{$\%$} \\
\hline Prototype 090 (MP 14 times) & $1: 8$ & 0 & $3.9 \times 10^{1}$ \\
\hline $090($ BAP $\times 25)$ & $1: 1$ & 95 & $2.5 \times 10^{4}$ \\
\hline 090 BAP $\times 25($ MP 25 times $)$ & $1: 8$ & 0 & $6.7 \times 10^{1}$ \\
\hline 090 BAP $\times 25(10 \% \Delta S 25$ times $)$ & $1: 16$ & 0 & $1.2 \times 10^{2}$ \\
\hline $508 \ddagger$ & $1: 1$ & 92 & $3.4 \times 10^{6}$ \\
\hline $508 \ddagger$ (MP 75 times) & $1: 1$ & 86 & $5.6 \times 10^{6}$ \\
\hline $508 \ddagger(10 \% \Delta S 25$ times $)$ & $1: 1$ & 88 & $1.4 \times 10^{7}$ \\
\hline
\end{tabular}

MP, mouse passed.

BAP, blood-agar plate.

$\Delta S, 10 \%$ concentration of low antibody serum in THB.

- Highest dilution of four-times concentrated growth medium that gave 3-4+ capillary precipitin reactions with hyperimmune rabbit antiserum to native type Ia antigen. I Identical results were obtained for strain 515 (not shown). 
TABLE IV

Antibody Facilitation of Alternative Pathway-mediated Opsonophagocytosis of Type Ia

(Strain 090) Group B Streptococcus

\begin{tabular}{|c|c|c|c|c|c|}
\hline \multirow[b]{2}{*}{ Serum source } & \multicolumn{2}{|c|}{$\begin{array}{l}\text { Type la GBS antibody } \\
\text { concentration }\end{array}$} & \multirow[b]{2}{*}{ Buffer } & \multicolumn{2}{|c|}{ Bactericidal index } \\
\hline & Mean & Range & & Mean & Range \\
\hline & \multicolumn{2}{|c|}{$\mu g / m l$} & & & \\
\hline 12 sera with low antibody levels & 2.1 & $1.8-3.5$ & $\mathrm{GVB}++$ & 11 & $0-76$ \\
\hline 12 sera with low antibody levels & 2.1 & $1.8-3.5$ & MgEGTA & 0 & - \\
\hline 3 sera with moderate antibody levels & 11.7 & $9-16.5$ & GVB++ & 85 & $73-91$ \\
\hline 3 sera with moderate antibody levels & 11.7 & $9-16.5$ & MgEGTA & 12 & $0-30$ \\
\hline 5 sera with moderate to high antibody levels & 15.6 & $5.9-32$ & $\mathrm{GVB}++$ & 88 & $81-94$ \\
\hline 5 sera with moderate to high antibody levels & 15.6 & $5.9-32$ & MgEGTA & 90 & $77-99$ \\
\hline
\end{tabular}

To further evaluate the classical pathway-mediated killing of strain 515 by serum containing low concentrations $(2.0 \mu \mathrm{g} / \mathrm{ml})$ of specific antibody, we performed a kinetic experiment (Fig. 4). Bacterial growth was observed in tubes containing MgEGTA buffer alone, heated and MgEGTA-treated antibody-deficient serum, and no WBC, whereas a $>1 \log _{10}$ reduction in inoculum was observed within $10 \mathrm{~min}$ of incubation of bacteria with antibody-deficient serum with endogenous complement. The rapidity with which opsonophagocytosis was observed was consistent with other experiments implicating classical pathway mediation.

To investigate a possible mechanism for antibodyindependent classical pathway activation by type Ia, group B streptococci, we performed the following experiments. Strain 515 was opsonized for $40 \mathrm{~min}$ at $37^{\circ} \mathrm{C}$ in untreated and heat-inactivated agammaglob-

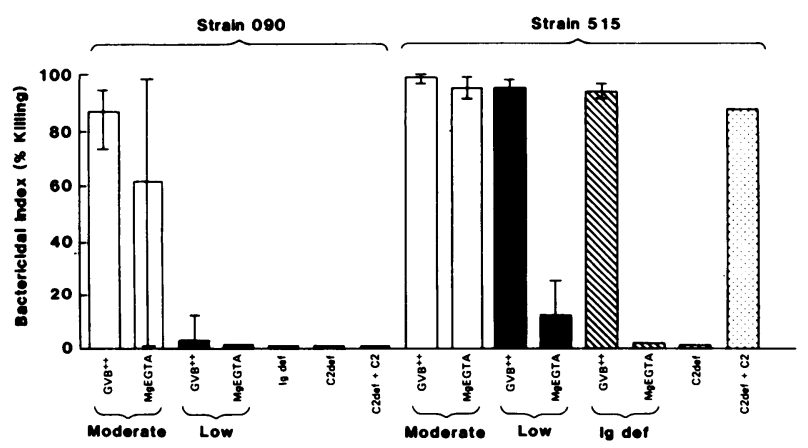

Figure 3 Opsonophagocytosis of prototype strain 090 and clinical isolate 515 by sera containing moderate $(9.0 \mu \mathrm{g} / \mathrm{ml})$ or low $(2.0 \mu \mathrm{g} / \mathrm{ml})$ concentrations of antibody to native type Ia polysaccharide by agammaglobulinemic serum (Ig def), by serum genetically deficient in C2 (C2 def), and by C2deficient serum with added purified $\mathrm{C} 2$ in $\mathrm{GVB}++$ or MgEGTA buffers. Mean and range of bactericidal indices for three experiments are listed for each serum. ulinemic serum. The experimental conditions were identical to those of the opsonophagocytic assay, except that WBC were replaced with $0.1 \mathrm{ml}$ of MEM. Bacteria were washed thoroughly and resuspended in $0.1 \mathrm{ml}$. of fluorescein-labeled anti-human Clq. Fluorescence $(3+)$ was observed for strain 515 in untreated serum but not in heated serum or when strain 515 was incubated in the absence of serum. That IgG was not mediating fixation of $\mathrm{Clq}$ in this serum was indicated by its absence on the bacterial surface of strain 515 after opsonization. These results indicate that under conditions of significant bacterial killing by agammaglobulinemic serum, fixation of $\mathrm{Clq}$ at the bacterial surface is observed for type Ia clinical isolate 515 .

Because it is conceivable, although unlikely, that the small amount of IgG present in agammaglobulinemic serum was mediating activation of classical pathway components, and since it is possible that antibodies to a surface antigen other than the type Ia capsular polysaccharide were mediating activation of $\mathrm{Cl}$ and the subsequent deposition of $\mathrm{Clq}$ at the bacterial surface, an additional experiment was designed. Strains 090 and 515 were opsonized in the presence of purified human $\mathrm{Cl}$. After washing and resuspending opsonized and unopsonized bacteria in fluorescein-labeled antihuman Clq, we noted strong (4+) fluorescence for strain 515, whereas we found no fluorescence for strain 090 or for either strain unexposed to $\mathrm{Cl}$. These results confirm other evidence indicating that the classical pathway is activated by clinical isolates of type Ia, group B streptococci in the absence of type-specific antibody and that immunoglobulin is not required for fixation of Clq at the bacterial surface.

\section{DISCUSSION}

The extensive work of Lancefield and co-workers (10, 20-22) has supported the concept that protective im- 
TABLE V

Antibody-independent Classical Pathway-mediated Opsonophagocytosis of Type Ia

(Strain 515) Group B Streptococcus

\begin{tabular}{|c|c|c|c|c|c|}
\hline \multirow[b]{2}{*}{ Serum source } & \multicolumn{2}{|c|}{$\begin{array}{l}\text { Type la GBS antibody } \\
\text { concentration }\end{array}$} & \multirow[b]{2}{*}{ Buffer } & \multicolumn{2}{|c|}{ Bactericidal index } \\
\hline & Mean & Range & & Mean & Range \\
\hline 3 sera with low antibody levels & 1.9 & $1.8-2.1$ & GVB++ & $95^{\circ}$ & 93-97 \\
\hline 3 sera with low antibody levels & 1.9 & $1.8-2.1$ & MgEGTA & $8^{\circ}$ & $0-25$ \\
\hline 3 sera with moderate to high antibody levels & 13.1 & $9-17$ & GVB++ & 98 & 97-99 \\
\hline 3 sera with moderate to high antibody levels & 13.1 & $9-17$ & MgEGTA & 96 & $91-99$ \\
\hline
\end{tabular}

- Paired $t$ test $(t=22.5, P<0.01)$.

munity to group B Streptococcus is mediated by antibody with specificity for the homologous capsular polysaccharide antigen (type-specific immunity). Employing prototype strains, passed in mice to enhance virulence, and type-specific rabbit antisera prepared to these strains, they were able to show passive protection after lethal challenge with homologous, but not heterologous, strains representing group B streptococcal serotypes Ia, Ib, Ic, and II. Although type III strains were not lethal in this standard animal model, type III-specific protective immunity has now been established in models for lethal infection in mice (23-25), chick embryos $(9,26)$, and suckling rats $(27)$.

In 1976, the first reports suggesting that human immunity to group B Streptococcus was correlated with

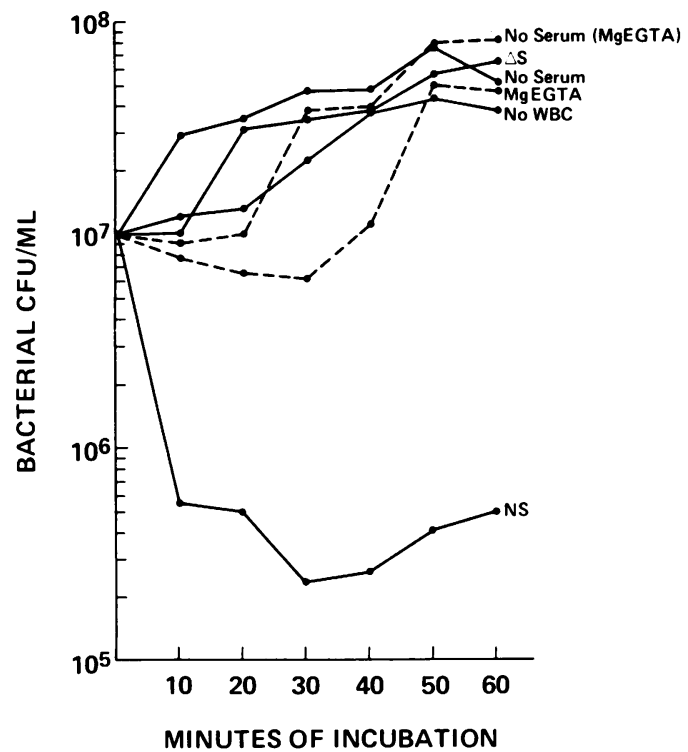

FIGURE 4 Kinetics of opsonophagocytosis of type Ia strain 515 by low specific antibody-containing serum (NS), heated serum $(\Delta)$, and MgEGTA-chelated low antibody serum (MgEGTA). Controls were no polymorphonuclear leukocytes (WBC), no serum, and no serum in the presence of MgEGTA. type-specific antibody appeared $(8,16)$. Because nearly two-thirds of isolates from young infants with invasive group B streptococcal infection belong to serotype III $(28,29)$, human immunity for this serotype has been studied more intensively than that for type I and type II strains. Several investigations have related a deficiency of antibody to the type III polysaccharide in a maternal serum to risk for invasive infection with type III strains in the neonate $(1,3,8,9,16)$. This presumably "protective" antibody has specificity for the native III polysaccharide $(2,5)$, is an IgG immunoglobulin $(1,8,9)$, and is placentally transferred in concentrations that, beyond 35-36 wk of gestation, approach that in maternal serum $(1,9)$. In addition, it promotes opsoniophagocytosis and killing of type III strains by polymorphonuclear leukocytes in the presence of complement $(4,18)$, is protective in animal models when sufficient concentrations are administered before or concomitant with challenge $(9,25,26)$, and can modify the terminal sialic acid moieties of the type III capsule in a manner that permits activation of the alternative pathway (4).

Previous reports have suggested that human immunity to type Ia, group B Streptococcus is analogous to that of serotype III $(7-9,30)$. In three of these studies, however, the presence of type Ia antibody in a serum was measured exclusively by functional assays (opsonophagocytosis $[7,30]$ or opsonization related to chemiluminescence [8]) that employed the mousepassed strain 090 as the only test organism. Our finding that phagocytosis and killing of this strain is dependent upon a critical amount of specific antibody (quantitated in a radioimmunoassay) is consistent with these observations $(7-9,30)$. However, the notable disparity between the opsonophagocytic requirements of human sera for this laboratory-adapted, highly encapsulated strain and those for type Ia strains freshly isolated from patients described in the present study suggest that the precise role of type-specific antibody and complement in human infection due to type Ia, group B Streptococcus should be reexamined. 
The potential importance of the experiments indicating in vitro killing of type Ia patient isolates by complement-mediated phagocytosis in human serum devoid of immunoglobulin prompted attempts to define the nature of the difference between these type Ia strains and the laboratory-adapted, prototype strain. Purified polysaccharides extracted from three representative clinical isolates and from strain 090 were chemically and immunologically identical (6). Therefore, the immunospecificity of the capsule did not vary and could not account for differences in the ability of these strains to activate the classical pathway. When the degree of encapsulation was assessed by electron microscopy, however, the prototype strain had an abundance of capsular material when compared with a representative clinical isolate (Fig. 2). Similarly, significantly greater quantities of type Ia polysaccharide were elaborated into the growth medium by strain 090 than by three patient isolates (Table III). That the difference in opsonophagocytic requirements by human sera for these different strains was directly related to amount of capsular polysaccharide material was shown by manipulation of the prototype strain (serial plate passage) to induce a smaller capsule. This maneuver resulted in a loss of capsule to a degree comparable to that of clinical isolates as assessed by electron microscopy, a decreased virulence for mice, and a loss of dependence on specific antibody for opsonophagocytosis by human serum. Reversion to a highly encapsulated variant was induced in this plate-passed 090 strain by serial passage in mice or in $10 \%$ human serum. Similar laboratory maneuvers for two fresh clinical isolates failed to influence opsonic requirements by human sera or mouse virulence. Selection of strain 090 as the prototype for serotype Ia by Lancefield (personal communication) was based upon its unusual degree of encapsulation compared with other strains and its ready adaptation to mouse virulence. Although selection for these characteristics enhances investigations requiring extraction of capsular material in large quantities or those defining protective antibodies in the mouse model, our inability to increase the capsular size of type Ia, group B streptococcal isolates suggests that 090 may be somewhat unique among these organisms. However, additional study of a large number of fresh clinical isolates would be required to substantiate this hypothesis.

These experiments suggest that the degree of encapsulation of type Ia, group B Streptococcus dictates the opsonophagocytic requirements by human serum. Perhaps, the abundance of capsular material on strain 090 masks surface sites that are available for direct complement activation by the fresh clinical isolates. However, the activating site is not known and other explanations for these observations are indeed possible.
Although it is not surprising that laboratory adaptation of microorganisms can influence degree of encapsulation, which, in turn, directly influences virulence in mice and opsonic requirements of adapted strains (pneumococci [31, 32], H. influenzae type b [33], and $S$. aureus [34]), it is important to emphasize that type Ia isolates associated with human infection resisted procedures known to enhance encapsulation and virulence for mice.

Similar to what has been reported for type III, group B Streptococcus $(4,18)$ in the presence of considerable amounts of type Ia-specific antibody $(\geqq 6 \mu \mathrm{g} / \mathrm{ml})$, both the prototype strain 090 and representative clinical isolate 515 could be opsonized and killed in sera chelated with MgEGTA. Therefore, clinical isolates of both of these serotypes of group B streptococci can activate the alternative complement pathway when sera contain a sufficient amount of type-specific antibody.

The most surprising observation in this study was that clinically relevant strains of type Ia, group B Streptococcus could be opsonized and killed in low specific antibody-containing or agammaglobulinemic sera. This finding indicates that opsonophagocytosis is independent both of type-specific antibody and of antibody directed against other antigenic determinants. This antibody-independent bactericidal activity of sera was ablated by MgEGTA treatment, indicating that it requires calcium and does not involve alternative complement pathway activation. That this antibody-independent opsonophagocytosis was mediated by activation of the classical pathway was also demonstrated when serum genetically deficient in C2 could not promote bacteriolysis of strain 515 until it was reconstituted with $\mathrm{C2}$.

The mechanism by which type Ia, group B streptococci initiate classical pathway activation in the absence of antibody is incompletely elucidated. In other systems, activation mediated by binding of $\mathrm{Cl}$ to a surface has been described. The experiments performed here indicate that immunoglobulin is not required for $\mathrm{Clq}$ fixation at the bacterial surface. If this $\mathrm{Cl}$ binding to the surface of type Ia strains can be shown to mediate activation of the classical pathway, as has been described for retroviruses (35), C-reactive protein (36), complexes of polyanions and polycations (37), certain gram-negative enteric bacilli $(38,39)$, and some strains of gram-positive bacteria (40-42), the definition of the surface component of the bacterium responsible for this binding will be important.

This study demonstrates that opsonophagocytosis of clinical type Ia, group B streptococci by human sera is mediated by the classical pathway in an immunoglobulin-independent manner. Whether $\mathrm{Cl}$ mediates this classical pathway activation by the binding of $\mathrm{Cl}$ 
to sites on the bacterial surface needs to be defined in future studies. In a preliminary study, sera from three healthy term neonates $<24 \mathrm{~h}$ of age promoted significant opsonophagocytosis of clinical isolate 515 , whereas strain 090 grew in each of these sera. It is possible, however, that the range in physiological deficiency of classical pathway components described for neonatal sera $(43,44)$ has critical functional significance that relates to the pathogenesis of type Ia, group B streptococcal disease in select hosts.

\section{ACKNOWLEDGMENTS}

The authors with to thank Marilee Shaffer and Terry Moreau for their technical assistance, Dixie Hargraves for her help with the preparation of the manuscript, and Dr. Ralph D. Feigin, for reviewing the manuscript.

This work was supported by research grant AI 13249 from the National Institute of Allergy and Infectious Diseases and by the Meyers-Black Mellon Enterprises Pediatric Infectious Disease Fund.

\section{REFERENCES}

1. Baker, C. J., D. L. Kasper, I. B. Tager, A. Paredes, S. Alpert, W. M. McCormack, and D. Goroff. 1977. Quantitative determination of antibody to capsular polysaccharide in infection with type III strains of group B Streptococcus. J. Clin. Invest. 59: 810-818.

2. Kasper, D. L., C. J. Baker, R. S. Baltimore, J. H. Crabb, G. Schiffman, and H. J. Jennings. 1979. Immunodeterminant specificity of human immunity to type III, group B Streptococcus. J. Exp. Med. 149: 327-339.

3. Baker, C. J., M. S. Edwards, and D. L. Kasper. 1981. The role of antibody to native type III polysaccharide of group B Streptococcus in infant infection. Pediatrics. 68: 544-549.

4. Edwards, M. S., A Nicholson-Weller, C. J. Baker, and D. L. Kasper. 1980. The role of specific antibody in alternative complement pathway-mediated opsonophagocytosis of type III, group B Streptococcus. J. Exp. Med. 151: $1275-1287$.

5. Jennings, H. J., K-G. Rosell, and D. L. Kasper. 1980. Structural determination and serology of the native polysaccharide antigen of type III group B Streptococcus. Can. J. Biochem. 58: 112-120.

6. Jennings, H. J., K-G. Rosell, and D. L. Kasper. 1980. Structure and serology of the native polysaccharide antigen of type Ia group B Streptococcus. Proc. Natl. Acad., Sci. U. S. A. 77: 2931-2935.

7. Mathews, J. H., P. H. Klesius, and R. A. Zimmerman. 1974. Opsonin system of the group B Streptococcus. Infect. Immun. 10: 1315-1320.

8. Hemming, V. G., R. T. Hall, P. G. Rhodes, A. O. Shigeoka, and H. R. Hill. 1976. Assessment of group B streptococcal opsonins in human and rabbit serum by neutrophil chemiluminescence. J. Clin. Invest. 58: 13791387.

9. Vogel, L. D., R. R. Kretschmer, K. M. Boyer, D. M. Padnos, C. A. Gadzala, and S. P. Gotoff. 1979. Human immunity to group B streptococci measured by indirect immunofluorescence: correlation with protection in chick embryos. J. Infect. Dis. 140: 682-689.

10. Lancefield, R. C., M. McCarty, and W. N. Everly. 1975.
Multiple mouse-protective antibodies directed against group B streptococci: special reference to antibodies effective against protein antigens. J. Exp. Med. 142: 165179.

11. Reed, L. J., and H. Muench. 1938. A simple method for estimating fifty per cent endpoints. Am. J. Hyg. 27: 493497.

12. Kasper, D. L., and C. J. Baker. 1978. Electron microscopic definition of surface antigens of group B Streptococcus. J. Infect. Dis. 139: 147-151.

13. Baker, C. J., and D. L. Kasper. 1976. Microcapsule of type III strains of group B Streptococcus: production and morphology. Infect. Immun. 13: 189-194.

14. McCarty, M., and R. C. Lancefield. 1955. Variation in the group-specific carbohydrate of group A streptococci. I. Immunochemical studies of the carbohydrates of the variant strains. J. Exp. Med. 102: 11-26.

15. Nydegger, U. E., D. T. Fearon, and K. F. Austen. 1978. The modulation of the alternative pathway of complement in C2-deficient human sera by changes in concentration of the component and control proteins. J. Immunol. 120: 1404-1410.

16. Baker, C. J., and D. L. Kasper. 1976. Correlation of maternal antibody deficiency with susceptibility to neonatal group B streptococcal infection. N. Engl. J. Med. 294: 752-756.

17. Gotschlich, E. C., M. Rey, R. Triau, and K. J. Sparks. 1972. Quantitative determination of the human immune response to immunization with meningococcal vaccines. J. Clin. Invest. 51: 89-96.

18. Edwards, M. S., C. J. Baker, and D. L. Kasper. 1979. Opsonic specificity of human antibody to type III polysaccharide of group B Streptococcus. J. Infect. Dis. 140: 1004-1008.

19. Baker, P. J., P. W. Stashak, and B. Prescott. 1969. Use of erythrocytes sensitized with purified pneumococcal polysaccharides for the assay of antibody and antibodyproducing cells. Appl. Microbiol. 17: 422-426.

20. Lancefield, R. C. 1934. A serological differentiation of specific types of bovine hemolytic streptococci (group B). J. Exp. Med. 59: 441-458.

21. Lancefield, R. C. 1938. Two serological types of group B hemolytic streptococci with related, but not identical, type-specific substances. J. Exp. Med. 67: 25-40.

22. Lancefield, R. C., and E. H. Freimer. 1966. Type-specific polysaccharide antigens of group B streptococci. $J$. Hyg. 64: 191-203.

23. Baltimore, R. S., D. L. Kasper, and J. Vecchitto. 1979. Mouse protection test for group B Streptococcus type III. J. Infect. Dis. 140: 81-88.

24. Fleming, D. O. 1980. Mucin model for group B type III streptococcal infection in mice. Infect. Immun. 27: 449454.

25. Baltimore, R. S., C. J. Baker, and D. L. Kasper. 1981. Antibody to group B Streptococcus type III in human sera measured by a mouse protection test. Infect. Immun. 32: 56-61.

26. Vogel, L. C., K. M. Boyer, S. P. Gotoff, D. L. Kasper, and C. J. Baker. 1980. Comparison of assays for antibody to group B Streptococcus, type III. J. Infect. Dis. 141: 530.

27. Fischer, G. W., G. H. Lowell, M. H. Crumrine, and J. W. Bass. 1978. Demonstration of opsonic activity and in vivo protection against group B streptoccoci type III by Streptococcus pneumoniae type 14 antisera. J. Exp. Med. 148: 776-786.

28. Wilkinson, H. W. 1978. Analysis of group B streptococ- 
cal types associated with disease in human infants and adults. J. Clin. Microbiol. 7: 176-179.

29. Baker, C. J. 1980. Group B streptococcal infections. Adv. Intern. Med. 25: 475-501.

30. Stewardson-Krieger, P. B., K. Albrandt, T. Nevin, R. R. Kretschmer, and S. P. Gotoff. 1977. Perinatal immunity to group B $\beta$-hemolytic Streptococcus type Ia. J. Infect. Dis. 136: 649-654.

31. Ward, H. K., and J. F. Enders. 1932. An analysis of the opsonic and tropic action of normal and immune sera based on experiments with the pneumococcus. J. Exp. Med. 57: 527-547.

32. McLeod, C. M., and M. R. Krauss. 1950. Relation of virulence of pneumococcal strains for mice to the quantity of capsular polysaccharide formed in vitro. J. Exp. Med. 92: 1-9.

33. Pittman, M. 1931. Variation and type specificity in the bacterial species Hemophilus influenzae. J. Exp. Med. 53: 471-492.

34. Koenig, M. G., and M. A. Melly. 1965. The importance of surface antigens in staphylococcal virulence. Ann. N. Y. Acad. Sci. 128: 231-250.

35. Bartholomew, R. M., and A. F. Esser. 1980. Mechanisms of antibody-independent activation of the first component of complement $(\mathrm{Cl})$ on retrovirus membranes. Biochemistry 19: 2847-2853.

36. Kaplan, M. H., and J. E. Volanakis. 1974. Interaction of C-reactive protein complexes with the complement system. J. Immunol. 112: 2135-2147.

37. Raepple, E., H. U. Hill, and M. Loos. 1976. Mode of interaction of different polyanions with the first $(\mathrm{Cl}$,
Ci), the second (C2) and the fourth (C4) component of complement. Immunochemistry. 13: 251-255.

38. Loos, M., B. Wellek, R. Thesen, and W. Opferkuch. 1978. Antibody-independent interaction of the first component of complement with gram-negative bacteria. Infect. Immun. 22: 5-8.

39. Clas, F., and M. Loos. 1981. Antibody-independent binding of the first component of complement (Cl) and its subcomponent Clq to the $\mathrm{S}$ and $\mathrm{R}$ forms of Salmonella minnesota. Infect. Immun. 31: 1138-1144.

40. Verhoef, J., P. K. Peterson, Y. Kim, L. D. Sabath, and P. G. Quie. 1977. Opsonic requirements for staphylococcal phagocytosis. Heterogeneity among strains. Immunology. 33: 191-197.

41. Verbrugh, H. A., W. C. Van Dijk, R. Peters, M. E. Van der tol, P. K. Peterson, and J. Verhoef. 1979. Staphylococcus aureus opsonization mediated via the classical and alternative complement pathways. Immunology. 36: 391-397.

42. Verbrugh, H. A., W. C. Van Dijk, R. Peters, M. E. Van Erne, M. R. Daha, P. K. Peterson, and J. Verhoef. 1980. Opsonic recognition of staphylococci mediated by cell wall peptidoglycan: antibody-independent activation of human complement and opsonic activity of peptidoglycan antibodies. J. Immunol. 124: 1167-1172.

43. Davis, C. A., E. H. Vallota, and J. Forristal. 1979. Serum complement levels in infancy: age related changes. $P e-$ diatr. Res. 13: 1043-1046.

44. Drew, J. H., and C. M. Arroyave. 1980. The complement system of the newborn infant. Biol. Neonate. 37: 209217. 